\title{
Ti-6Al-4V 合金の疲労き裂伝ぱ挙動に及ぼす異方性の影響
}

\author{
橘 内良 雄* 田中正清* \\ 吉久悦 二**本田尚*
}

\section{Influence of Anisotropy on Fatigue Crack Growth \\ Behavior of Ti-6Al-4V Alloy}

by

\author{
Yoshio KitsunaI*, Masazumi TanaKa*, Etsuji Yoshinisa* \\ and Takashi HONDA*
}

The fatigue crack growth tests under constant amplitude and two-step program loadings were carried out to assess the effect of anisotropy on the crack growth of a forged Ti-6Al-4V alloy. CT specimens were cut from three different orientations with regard to the rolling direction of the material. Crack closure was measured by a compliance method to examine the overloading effect on the crack growth during the two-step program loading. Fracture surface morphologies were examined by a scanning electron microscope to assess the crack growth mechanism of the material tested. It was found that the crack growth rate was almost independent of the orientation of the material, regardless of loading condition. The crack opening stress intensity under the two-step program loading was almost the same in each block and was governed by the maximum stress intensity factor in the block. The fatigue crack growth rate under two-step program loading was correlated well with an effective stress intensity factor range estimated based on the linear accumulation of the stress intensity factor ranges of each step in the block. Cleavage facets occupied the major portion of fracture surface of low $\Delta K$ region under constant amplitude loading. Fracture surface under program loading was covered with striations corresponding to the loading sequence. Large striation due to overloading seems to be formed through the blunting and resharpening mechanism at crack tip.

Key words : Fatigue crack growth, Anisotropy, Program loading, Crack closure,

Fractography, Ti-6Al-4V

\section{1 緒 言}

チタン合金は比強度が高く, 耐熱, 耐食性にも優れ ていることから, 航空機をはじめとして, 海洋機器 や化学装置に広く使用されている. とりわけ， $\alpha$ 相 (hcp 構造) $+\beta$ 相 (bcc 構造) を有する $\mathrm{Ti}-6 \mathrm{Al}-4 \mathrm{~V}$ は，代表的なチタン合金として知られており，耐熱性 や軽量化の観点から今後ますます多方面で活用される ものと思われる. しかし, Ti-6Al-4V は bcc や f c c 構造の鋼やアルミ合金とは異なり，組織感受性や異方 性が強く，鉄鋼材料で認められるような引張り強さと 疲労強度の間に相関が存在しないことが指摘されてい る. このため, 微視組織が疲労寿命や疲労き裂伝ぱ举 動に及ぼす影響が各種の条件下で調べられている。異 方性の影響については，菅野らが純チタンを用いて詳 細な研究を行っているが, チタン合金についての結果 は少ないようである。本研究では，工業的に最も多く 使用されている Ti-6Al-4V 合金について，一定振幅 荷重および 2 段変動荷重試験を行い, 疲労き裂伝ば挙
動に及ほす異方性の影響について検討した。また，き 裂伝ぱ機構についての知見を得るために，フラクトグ ラフイによる検討を行った.

\section{2 試験片および実験方法}

実験に供した Ti-6Al-4V は鍛造した直径 $150 \mathrm{~mm}$ の丸棒（鍛造比約 3.6）であって，化学成分を Table Iに，C-L および L-C 方向から採取した引張り試験

Table I. Chemical composition of material used (wt. \%).

\begin{tabular}{c|c|c|c|c|c}
\hline $\mathrm{Ti}$ & $\mathrm{Al}$ & $\mathrm{V}$ & $\mathrm{Fe}$ & $\mathrm{O}$ & $\mathrm{N}$ \\
\hline val. & 6.75 & 4.50 & 0.30 & 0.20 & 0.050 \\
\hline
\end{tabular}

Table II. Mechanical properties of material used.

\begin{tabular}{c|c|c|c}
\hline Orientation & $\begin{array}{c}\text { Yield } \\
\text { strength } \\
\text { (MPa) }\end{array}$ & $\begin{array}{c}\text { Tensile } \\
\text { strength } \\
\text { (MPa) }\end{array}$ & $\begin{array}{c}\text { Elongation } \\
(\%)\end{array}$ \\
\hline C-L & 901 & 964 & 13.6 \\
L-C & 917 & 964 & 13.2 \\
\hline
\end{tabular}

†原稿受理 平成 5 年 8 月 16 日 Received Aug. 16, 1993

* 正会 員 産業安全研究所 テ204 清瀬市梅園, Res. Inst. of Indust. Safety, Umezono, Kiyose, 204 


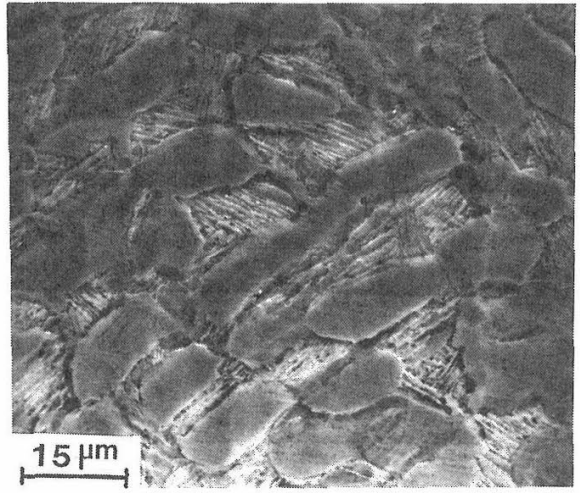

Fig. 1. Microstructure of $\mathrm{L}-\mathrm{C}$ orientation of $\mathrm{Ti}-6 \mathrm{Al}-4 \mathrm{~V}$.

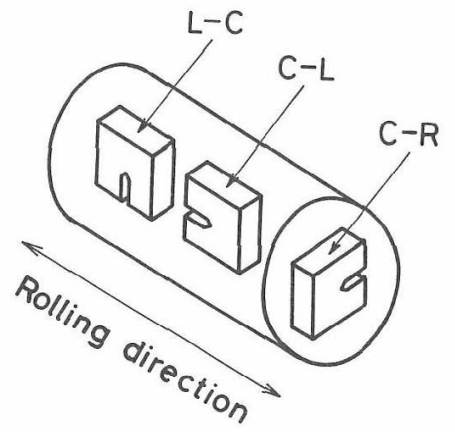

Fig. 2. Specimen orientation with respect to the rolling direction.

片の機械的性質を Table II に示す。 また，供試材の L-C 方向の金属組織を Fig. 1 に示す.

試験片は，Fig. 2 に示すように，C-R，C-L および L-C の 3 方向から採取した。試験片の形状は板厚 10 $\mathrm{mm}$ ，板幅 $51 \mathrm{~mm}$ の CT 試験片である.

疲労き裂伝ば試験は電気油圧式疫労試験機を用いて, 一定振幅荷重扮よび 2 種数のプログラム荷重 $\mathrm{A}, \mathrm{B}$ を負荷して行った。応力比 $\mathrm{R}$ はいずれも 0.05 , 荷重 波形は正弦波であって, 繰返し速度は一定振幅荷重で は $8 \sim 15 \mathrm{~Hz}$ ，プログラム荷重の場合は $0.5 \sim 5 \mathrm{~Hz}$ で ある，プログラム荷重試験は式 (1)で定義する過荷重 比 OLR が 100\% となるように, 変動荷重振幅を定め た。

$$
\mathrm{OLR}=\left[\left(P_{\mathrm{OL}}-P_{\mathrm{MB}}\right) / P_{\mathrm{MB}}\right] \times 100
$$

ここで， $P_{\mathrm{MB}}$ は基準荷重の最大值， $P_{\mathrm{OL}}$ は過大荷重の 最大値である。

各ステップの繰返し数 $N_{i}$ と 1 ブロック当りの総繰 返し数 $\sum N$ は, プログラム荷重 A では, $N_{1}=99, N_{2}$

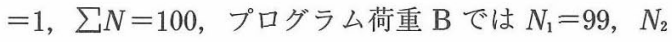
$=1, N_{3}=9, \quad N_{4}=1, N_{5}=379, \quad N_{6}=1, N_{7}=9, N_{3}=1$, $\Sigma N=500$ である。㤠伝ぱ速度 $d a / d N$ は，一定振 幅荷重では Secant 法により求めた。変動荷重の場合 は，1ブロック当りのき裂伝ぱ長さ $\Delta a$ を 1 ブロック
の総繰返し数 $\Sigma N$ で除すことにより求めた。き裂開 口荷重の測定は, 試験片の背面に $2 \mathrm{~mm}$ のひずみゲー ジを貼り, 引算回路を用いてコンプライアンス法によ り行った，疲労試験後すべての破面について，走査電 子顕微鏡を用いて観察を行った。

\section{3 実験結果および考察}

\section{$3 \cdot 1$ 一定振幅荷重下の疲労き裂伝ぱ挙動}

Fig. 3 は一定振幅荷重下の疲労き裂伝ぱ速度と $\Delta K$ の関係を示したもので, $15<\Delta K<40 \mathrm{MPa} \sqrt{\mathrm{m}}$ の範 囲の $d a / d N$ と $\Delta K$ に対して最小自乗法を適用して 求めたParis 則の $m$ の值は $2.8 \sim 3.3$ である. $d a / d N$ を比較すると， C-L 方位のデータが若干高速側にプ ロットされる傾向にあるが，ばらつきを考虑すると Paris 則の成立範囲に㧧いて $d a / d N$ に顕著な異方性 は存在しない. $\Delta K<15 \mathrm{MPa} \sqrt{\mathrm{m}}$ においても $\mathrm{C}-\mathrm{L}$ と L-C 方位の $d a / d N$ は同様な挙動を示して扔り,ま た $\Delta K_{\mathrm{th}}$ もそれぞれ $5.76,5.88 \mathrm{MPa} \sqrt{\mathrm{m}}$ であって, 両者はほぼ一致している。この結果から明らかなよ うに，き裂の伝ぱが微視組織の影響を受け安くなる 低 $\Delta K$ においても, 異方性は認められない. Fig. 4 は き裂開口比 $U$ と $K_{\max }$ の関係を示したもので, デー タのばらつきを勘案すると，Uに異方性の影響は反 映されていない. Fig. 4 に扔いて， $K_{\max }$ が約 15 $\mathrm{MPa} \sqrt{\mathrm{m}}$ 以下では $K_{\max }$ と共に $U$ も増加し, $15<$ $K_{\max }<40 \mathrm{MPa} \sqrt{\mathrm{m}}$ ではほほ $U$ が一定となり, 最終破 壞近傍の $K_{\max }>40 \mathrm{MPa} \sqrt{\mathrm{m}}$ では再び増加し, 約 1 と

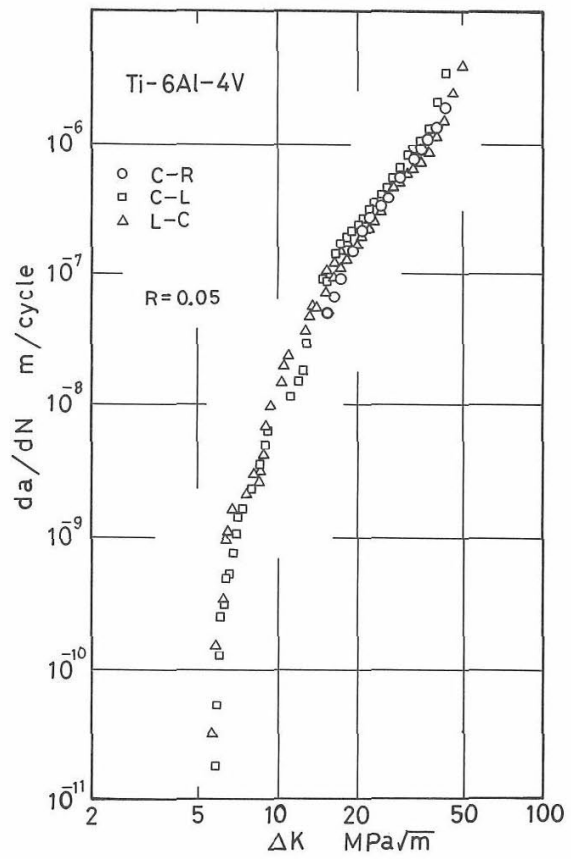

Fig. 3. Effect of anisotropy on fatigue crack growth rate under constant amplitude loading. 


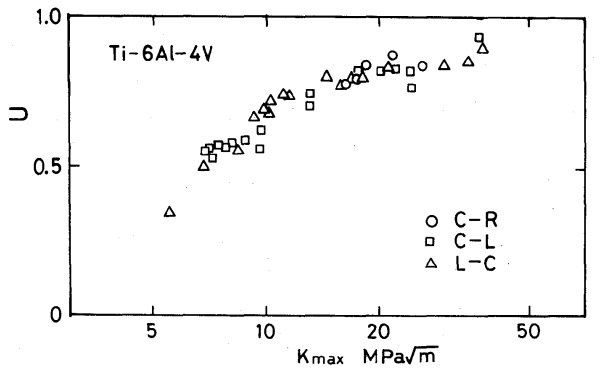

Fig. 4. Relationship between crack opening ratio, $U$, and $K_{\max }$ under constant loading.

なっている.このような $U$ の変化はこれまで他の材 料で計測されたデー夕と同様な傾向を示している.

\section{$3 \cdot 2$ プログラム荷重下の疲労き裂伝ぱ挙動}

プログラム荷重試験において，1ブロック当りの平 均的なき裂伝ぱ速度を式 (2) で示す等価応力拡大係数 範囲に対してプロットした結果を Fig. 5 に示す.

$$
\Delta K_{m}=\left(\sum_{i=1}^{2} \Delta K_{i}^{m} \frac{N_{i}}{\sum N_{i}}\right)^{1 / m}
$$

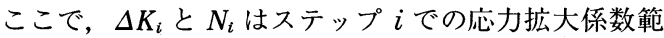
囲と繰返し数である. 式 (2)の $m$ は, 一定振幅荷重 下での Paris 則の $m$ が 2.8 3.3であったことから， その平均値をとり $m=3$ を採用した.

Fig. 5 に見られるように，プログラム A および B のいずれの変動荷重の場合においても， $d a / d N$ に異 方性は現れてはいない，また，変動荷重下の $d a / d N$ は高 $\Delta K$ 域を除いて, 散布带で示す一定振幅の $d a$ / $d N$ よりも低下しており，これまで種々の材料で報告 されている結果と定性的には一致している. 変動荷重

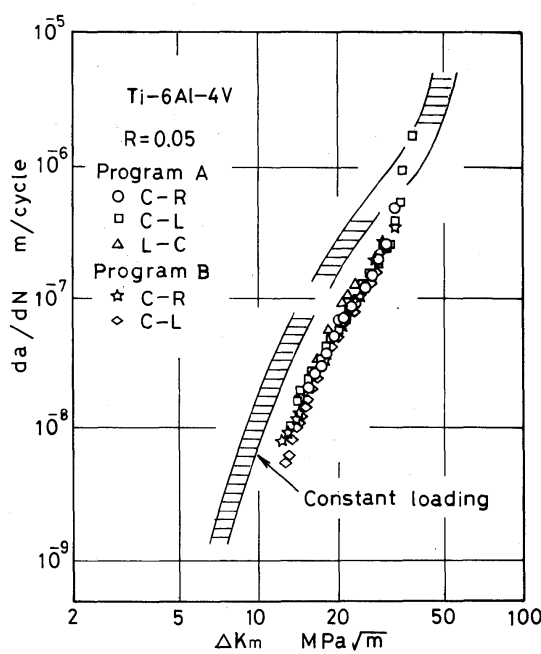

Fig. 5. Effect of anisotropy on fatigue crack growth rate under two-step program loading.

下における $d a / d N$ に遅延が生じる要因として，き裂 開閉口，き裂の偏向，き裂先端の加工硬化，フレティ ング酸化物等が報告されている。これらのうち，き裂 開閉口が最も重要と考えられる。そこで, 変動荷重下 のき裂開口荷重 $P_{\mathrm{op}}$ の計測を行った. Fig. 6 は, プロ グラム B を負荷した場合の荷重と，引算回路を用い たき裂開口変位線図を，記録紙を送りながら X-Y レ コーダに記録した結果であって，過大荷重を負荷する 以前（図中の B ）と以後（図中の A）でき裂開ロレ ベルに変化は見られず，また，過大荷重を含めたき裂 開口荷重 $P_{\mathrm{op}}$ は一点鎖線で示すように，ほぼ一定と なっている．なお， $P_{\mathrm{op}}$ は負荷レベルや試験片の方位

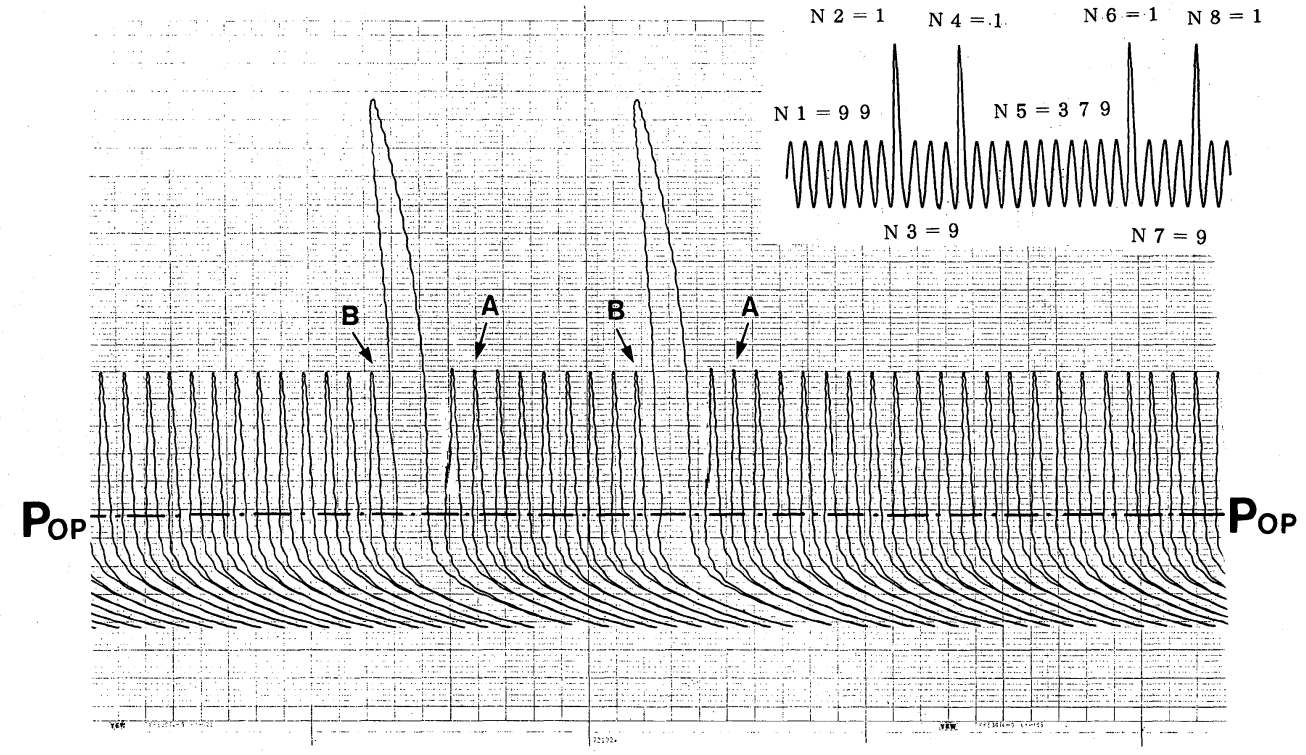

Fig. 6. Load-subtracted displacement curves under two step program loading. 


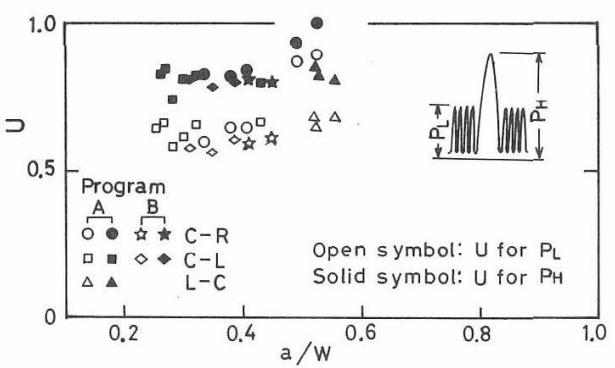

Fig. 7. Relationship between crack opening ratio, $U$, and crack length ratio, $a / W$, under two-step program loading.

によらず，1ブロック中ではほほ一定の值となってい る. $P_{\mathrm{op}}$ の測定結果を基にき裂開口比 $U$ を求めて, き裂長さ比 $a / W$ に対してプロットした結果をFig. 7 に示す。図に見られるように，プログラム A，B 共 にオープンシンボルで示す基準荷重のき裂開口比 $U_{\mathrm{L}}$ は，ソリッドシンボルで示す過大荷重のき裂開口比 $U_{\mathrm{H}}$ よりも低下している. 変動荷重下の $U$ は $K_{\max }$ が 約 25 60 MPa $\sqrt{\mathrm{m}}$ の範囲に対する結果であるが，こ の結果を Fig. 4 の $K_{\max }$ のはば等しい範囲の $U$ と比較 すると，荷重振幅の大きい過大荷重の $U$ （すなわち $\left.U_{\mathrm{H}}\right)$ とほほ等しくなっている。しかし， $U_{\mathrm{L}}$ は 0.63 程 度であって，一定振幅荷重の場合の $U$ よりもかなり 小さく, 過大荷重によって作られた塑性域の影響を受 けて，き裂が開口しにくくなっていることを示してい る.

\section{$3 \cdot 3$ 有効応力拡大係数範囲とき裂伝ぱ速度}

前記したように，き裂開口荷重レベル（き裂開口応 力拡大係数 $K_{\mathrm{op}}$ ) は 1 ブロック中ではほぼ一定であっ た。したがって変動荷重下に扔けるき裂伝ぱ速度は， 各ステップの最大応力拡大係数 $K_{i \max }$ から $K_{\mathrm{op}}$ を減 じた有効応力拡大係数範囲によって支配されると考え られる.この有効応力拡大係数範囲 $\Delta K_{i \text { eff }}$ は, 式 (3) によって与えられる。

$$
\Delta K_{i \text { eff }}=K_{i \max }-K_{\mathrm{op}}=U_{i} \Delta K_{i}
$$

ここで $U_{i}$ は各ステップのき裂開口比である.

この $\Delta K_{i \text { eff }}$ を式 (2)の $\Delta K$ に代入すれば有効応力 拡大係数範囲の $m$ 乗重み平均が算出できる。

$$
\Delta K_{\text {eff } m}=\left(\sum_{i=1}^{2} \Delta K_{i \text { eff }}^{m} \frac{N_{i}}{\sum N_{i}}\right)^{1 / m}
$$

式 (4) で定義した有効応力拡大係数範囲の $\mathrm{m}$ 乗重み 平均を用いて変動荷重下の $d a / d N$ を整理するに当り, き裂開口比 $U_{i}$ を Fig. 7 の結果から, $U_{1}=0.63, U_{2}$ $=0.82$ と定めた．また，一定振幅荷重の U は Fig. 4 に示したように, $15<K_{\max }<40 \mathrm{MPa} \sqrt{\mathrm{m}}$ で 0.8 程度 となっていることから $U=0.8$ とした。 これらのき裂 開口此を基に，一定振幅荷重では $\Delta K_{\mathrm{eff}}=U \Delta K$ を，

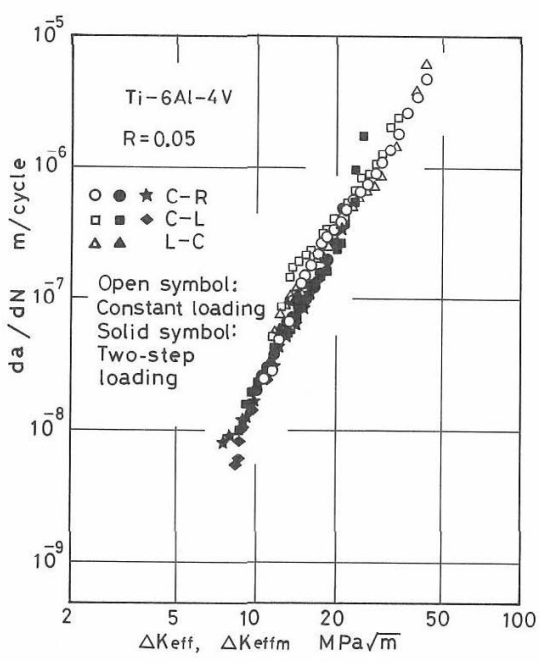

Fig. 8. Relationship between $d a / d N$ and effective stress intensity factor range, $\Delta K_{\text {eff }}, \Delta K_{\text {effm }}$, under constant amplitude and two-step program loadings.

変動荷重では式 (4)に示す有効応力拡大係数範囲を用 いて Fig. 3 の一定振幅何重㧍よび Fig. 5 の变動何重の $d a / d N$ の再整理を行った. Fig. 8 はその結果を示し たもので, 各 $d a / d N$ は傾斜が約 3 の比較的狭い散布 带中にプロットされ，本方法による $d a / d N$ の整理が 有効であることがわかる。

\section{$3 \cdot 4$ フラクトグラフィ}

一定荷重振幅の場合, $\Delta K<10 \mathrm{MPa} \sqrt{\mathrm{m}}$ の低 $\Delta K$ 域では方位によらずへき開状の形態が出現し，その割 合は $\Delta K_{\mathrm{tn}}$ に近づくにつれて増加する．Fig. 9 は一例 として L-C 方位の $\Delta K_{\mathrm{th}}$ 近傍の破面を示したもので, $\alpha$ 相に対応寸ると思われるファセットにへき開段が形 成されている。前記したように $\alpha$ 相は hep 構造を有

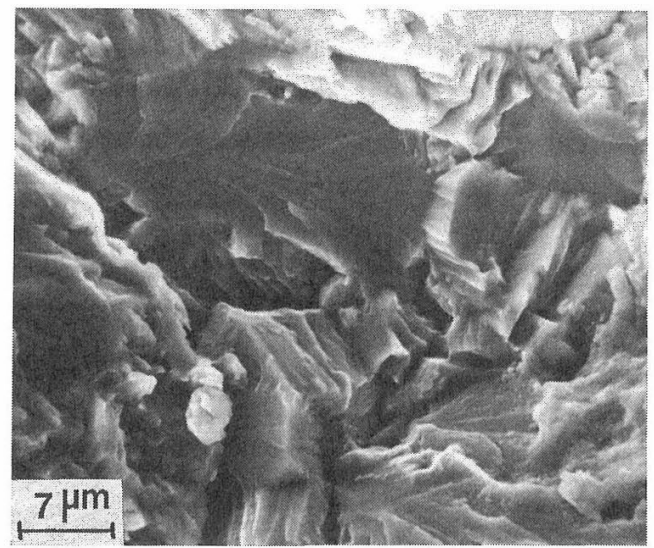

Fig. 9. Fractograph showing cleavage formed in low $\Delta K$ region under constant amplitude loading. $\Delta K=6.3 \mathrm{MPa} \sqrt{\mathrm{m}}, d a / d N=3.43$ $\times 10^{-10} \mathrm{~m} /$ cycle. L-C orientation. 


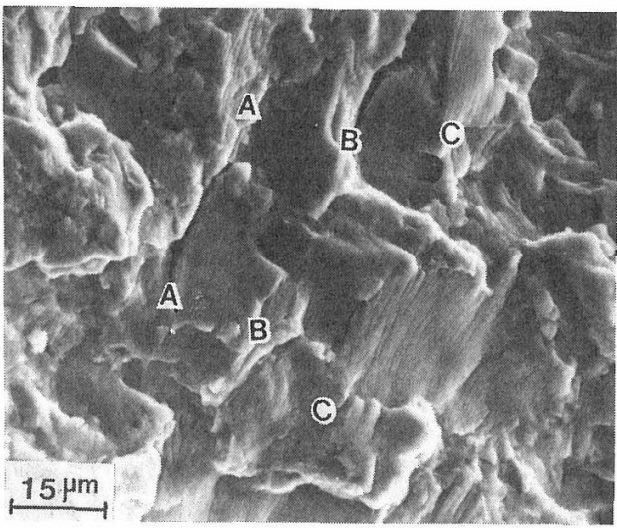

Fig. 10. Fractograph showing striation under constant amplitude loading. $\Delta K=30.9$ $\mathrm{MPa} \sqrt{\mathrm{m}}, \quad d a / d N=6.48 \times 10^{-7} \mathrm{~m} /$ cycle. $\mathrm{C}-\mathrm{R}$ orientation.

しており，すべり面とへき開面が一致するので， $\alpha$ 相 中のすべり变形が粒界や針状組織を有する $\beta$ 相に阻 止されるために，へき開が発生すると推察される。 ステレオ観察の結果，隣接へき開ファセット間でか なりの段差が作られている場合が多く，すべりが支配 的な炭素鋼の $\Delta K_{\mathrm{th}}$ 近傍よりも破面の凹凹が激しかっ た.このためチタン合金の場合には炭素鋼よりも破面 あらさが $\Delta K_{\mathrm{ln}}$ に影響すると推察される. $\Delta K>15$ $\mathrm{MPa} \sqrt{\mathrm{m}}$ からはストライエーションが支配的な破面 形態となっている (Fig. 10). ストライエーションは 多くの場合，一定の幅を有する帯状したプラトー部分 (Fig. 10 の A-B，B-C間）に作られており，高 $\Delta \mathrm{K}$ 域では帯状部分が隣接する境界において, 破面に垂直 な二次き裂がしばしば認められる.この帯の幅は Fig. 1 に示した $\alpha$ 相の幅と大略等しいことから，き裂が $\alpha$ 相を選択的に伝ぱしているものと推察される。なお， ストライエーションの間隔はき裂伝ぱ速度とほぼ一致 している.

Fig. 11 (a) はプログラム A を，Fig. 11 (b) はプログ ラム B を負荷した場合の破面形態を示したもので, プログラム荷重の場合にも異方性の影響は破面形態に 反映されておらず，プログラムの過大荷重に対応した 大きなストライエーション (Fig. 11 (b) の 1, 3, 5, 7) が形成されている，なお，高き裂伝ぱ速度域では大き なストライエーションの間に，基準荷重に対応する小 さな間隔のストライエーションが作られている場合が 多い. 過大荷重と次の過大荷重が作用した場合に作ら れる大きな 2 個のストライエーション間隔，すなわち， 1 ステップあるいは 1 ブロックのき裂伝ぱ距離は，そ れが形成された $\Delta K_{\text {eff } \mathrm{m}}$ または $\Delta K_{\text {eff }}$ に対応する $d a /$ $d N$ (Fig. 8) に1 ステップあるいは 1 ブロックの繰 返し数 $\left(N_{i}, \sum N\right)$ を乗じて求めた長さとほぼ一致して

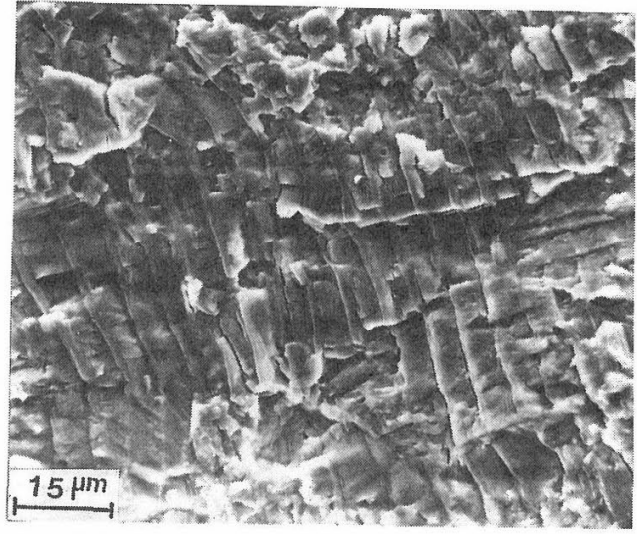

(a) Program loading A, $\Delta K_{\text {eff }}=11.8 \mathrm{MPa} \sqrt{\mathrm{m}}, d a / d N$ $=4.20 \times 10^{-8} \mathrm{~m} /$ cycle, $\mathrm{C}-\mathrm{L}$ orientation.
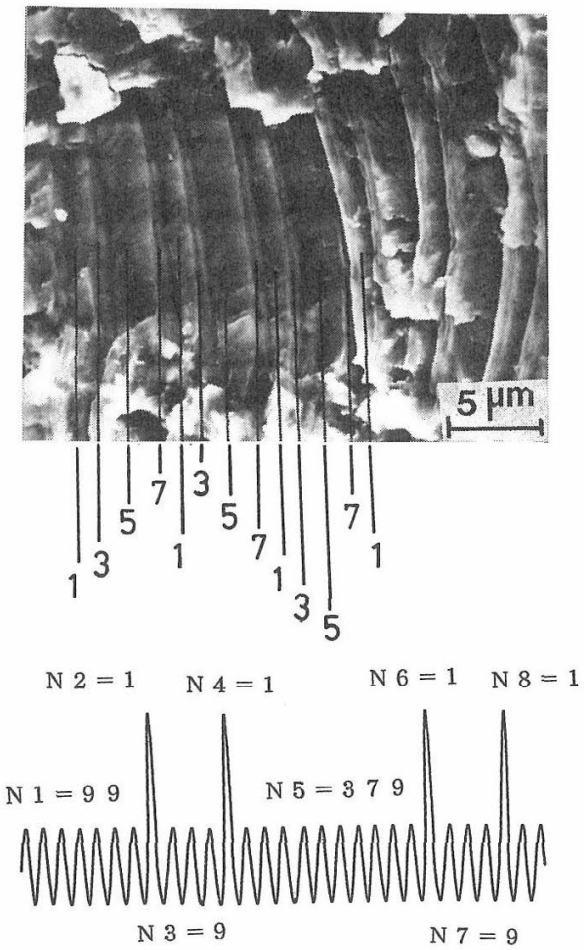

(b) Program loading B, $\Delta K_{\text {erf } \mathrm{m}}=10.5 \mathrm{MPa} \sqrt{\mathrm{m}}, d a / d N$ $=2.41 \times 10^{-8} \mathrm{~m} /$ cycle, $\mathrm{C}-\mathrm{L}$ orientation.

Fig. 11. Fracture morphologies resulting from application of two-step program loadings.

いる.このような関係は，変動荷重を受ける実機が破 壞した場合に, 変動荷重間の繰返し回数を推定するの に利用できる。

変動荷重の場合, 各ステップの負荷レベルによって き裂が $45^{\circ}$ に偏向しながらジグザグに伝ぱする結果や， 過大荷重負荷位置では一対の破面が凹と凸に対応する 結果が報告されている。そこで，本実験のように過大 荷重比が $100 \%$ の場合の一対の破面形状について検討 するため，ステレオ・マッチングの手法を適用した。 

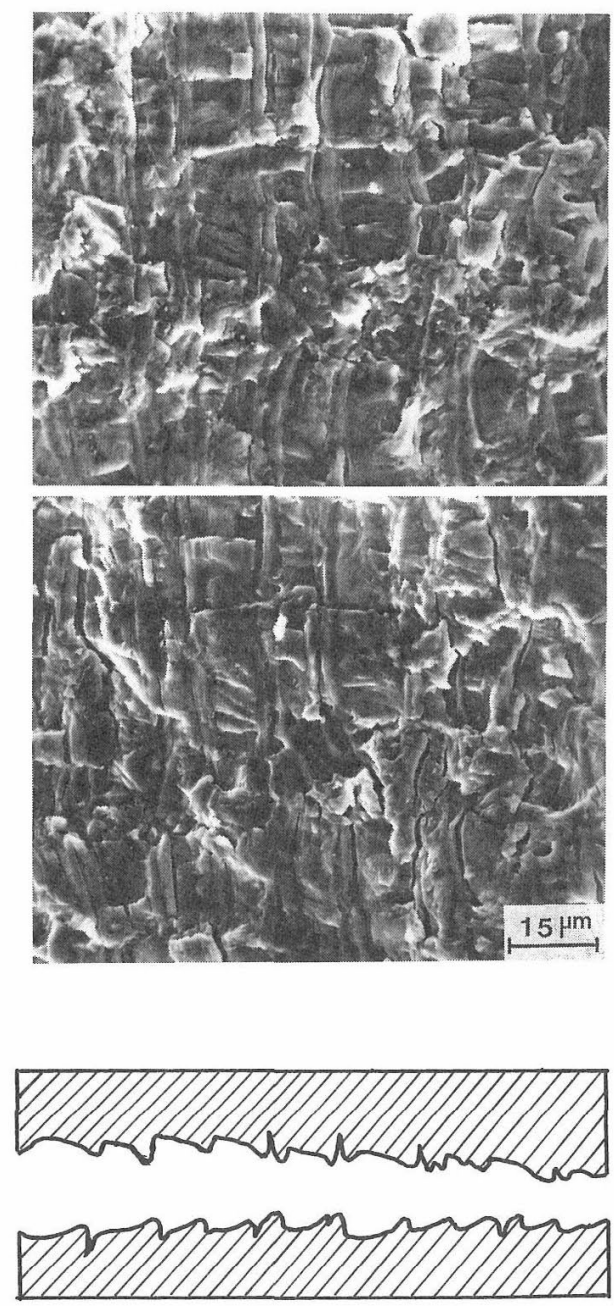

Fig. 12. Matching fractographs of fracture surfaces resulting from application of two-step program loading and schematic illustration of fracture surfaces contours. Program loading B $\Delta K_{\text {eff } m}$ $=14.1 \mathrm{MPa} \sqrt{\mathrm{m}}, d a / d N=6.40 \times 10^{-8} \mathrm{~m} /$ cycle, $\mathrm{C}-\mathrm{L}$ orientation.

Fig. 12 は，L-C 方位の試駼片に対して，プログラム B の荷重を負荷した場合の破面のマッチング写真と 破面形状をモデル的に示したもので， 3 次元的形状は かなり複雑に変化しているが，過大荷重が作用した部 分はストレッチゾーンと類似の形状となっている場合 が多く，基本的にはこれまで示されているストライエ ーションモデルと同様, き裂先端の開口と鈍化を反映 した形状となっている.

\section{4 結 論}

鍛造比が約 3.6 の Ti-6Al-4V 合金製の丸棒から CT 試験片を作製して，一定荷重振幅および二段変動 荷重試験を行い，き裂伝ぱ挙動に及はす寸異方性の影響 を調べた、結果は以下のように要約される。
（1）鍛造した Ti-6Al-4V 合金の疲労き裂伝ぱ速度 には，一定振幅荷重㧍よびプログラム変動荷重のいず れの場合に㧍いても，異方性の影響は認められない。

（2）変動荷重下に打けるき裂開口荷重は，過大荷重 が負荷される直前と過大荷重負荷後で変化は認められ ず，1ブロック中ではほぼ一定となっている，過大荷 重のき裂開口比 $U_{\mathrm{H}}$ は, 基準荷重の開口比 $U_{\mathrm{L}}$ よりも 高く, $U_{\mathrm{H}}$ は一定荷重振幅に扝けるき裂開口比 $U$ とほ ぼ同レベルとなっている.

（3） 2 種類のプログラム荷重（二段変動荷重）のき 裂伝ぱ速度は, 各段の最大応力拡大係数からき裂開口 応力拡大係数を減じた応力拡大係数範囲を 3 乗重み平 均した有効応力拡大係数範囲を用いて整理することが できる.

(4) Ti-6Al-4V 合金の $\Delta K<15 \mathrm{MPa} \sqrt{\mathrm{m}}$ の低 $\Delta K$ 域ではへき開ファセットが, $\Delta K>15 \mathrm{MPa} \sqrt{\mathrm{m}}$ の高 $\Delta K$ 域ではストライエーションが支配的な破面形態と なっている.

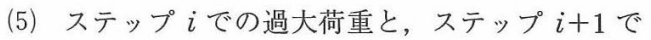
の過大荷重によって作られる 2 個の大きなストライエ ーションの間隔，すなわちステップ $i$ からステップ

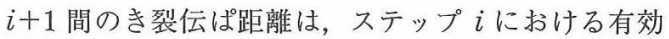
応力拡大係数範囲 $\Delta K_{\text {eff }}$ あるいは $\Delta K_{\text {effm }}$ に対応する $d a / d N$ に, ステップ $i$ からステップ $i+1$ 間までの 繰返し数を乗じた值とほぼ等しい。

（6）過大荷重によって作られるストライエーション の形状は，き裂先端の開口と鈍化を反映した形状と なっている.

(平成 5 年 6 月 24 日 日本材料学会第 8 回フラクトグラフィシンポジウ ムにて講演）

\section{参考文 献}

1) 皆川邦典, 鉄と鋼, 75, 1104 (1989).

2）たとえば，第21回疲労シンポジウム講演論文集 (1992) 日本材料学会

3) 菅野幹男, 梅津憲由, 佐竹忠昭, 材料, 41, 48 (1992).

4 ) E. F. J. von Euw, R. W. Hertzberg and R. Roberts, ASTM STP 513, 230 (1972).

5 ）松岡三郎, 田中紘一, 日本機械学会論文集, 44, 375 (1978).

6 ）菊川 真, 城野政弘, 近藤良之, 日本機械学会論文集, A-49, 278 (1983).

7 ) 小林英男, 虂内良雄, 井野幸雄, 成本朝雄, 岩館忠雄, 飯田国廣, 日本機械学会論文集，A-50，820（1984）.

8 ) 城野政弘, 菅田 淳, 日本機械学会論文集, A - 50, 1821 (1984).

9 ) S. Suresh, Eng. Fract. Mech., 18, 577 (1983).

10) J. F. Knott and A. C. Pickard, Metal Science, 11, 399 (1977).

11) S. Suresh, Scripta Metall., 16, 995 (1982).

12）小寺沢良一，志茂大治郎，近藤潤一，材料， 27，54 (1978). 